Frontiers: The Interdisciplinary Journal of Study Abroad (C) 2021 Kris Acheson, Lan Jin, Aletha Stahl, Katherine Yngve The work is licensed under the Creative Commons Attribution-NonCommercialNoDerivatives 4.0 International License.

Volume 33, Issue 1, pp. 1-10

DOI 10.36366/frontiers.v33.i1.624

\title{
Introduction:
}

\section{Special Issue on Assessment as Pedagogy in Education Abroad}

\author{
Kris Acheson ${ }^{1}$, Lan Jin $^{1}$, Aletha Stahl ${ }^{1}$, Katherine Yngve $^{1}$
}

\begin{abstract}
This essay introduces the Special Issue on Assessment as Pedagogy in Education Abroad, which seeks to answer the question: How can we guide educators toward specific and intentional alignment of learning objectives, the learning context, and learner capacities and needs so that students achieve the desired learning outcomes? The Guest Editors briefly describe the articles selected for the special issue, focusing on three categories: Macro-Level Studies, Micro-Level Studies, and Innovative Approaches. Future directions for assessment in education abroad are suggested, with a focus on leveraging assessment to increase community reciprocity, cultural responsiveness, differentiated learning, and access in education abroad.
\end{abstract}

\section{Abstract in Spanish}

Este ensayo presenta la colección especial de Frontiers sobre el tema, "El uso pedagógico de la evaluación de aprendizaje," que trata la cuestión de ¿cómo se puede guiar los maestros en la planificación intencional de alcanzar objetivos de aprendizaje en contextos específicos y con una variedad de capacidades estudiantiles? El equipo de editoras invitadas describe resumidamente los artículos incluidos en la colección, enfocando en tres categorías: los estudios de

1 Purdue University, West LAFAyette, IN, USA

Corresponding Author: Kris Acheson, krisac@purdue.edu 
investigación a nivel macro, los a nivel micro, y los estudios con métodos innovadores. Se ofrecen recomendaciones para futuras investigaciones en el área de estudios de la educación internacional, con énfasis en el aprovechamiento de la evaluación de aprendizaje estudiantil para mejorar la reciprocidad comunitaria, la capacidad de sensibilidad cultural, la enseñanza diferenciada, y el acceso a la educación internacional.

\section{Abstract in French}

Dans cet essai, nous présentons le numéro spécial sur l'évaluation comme outil didactique, sujet destiné à répondre à la question : Comment guider les éducateurs à aligner les objectifs d'apprentissage, le contexte d'apprentissage, ainsi que les capacités et les besoins des étudiants afin que s'achevent les résultats d'apprentissage visés ? L'équipe de rédacteurs invités décrit en résumé les articles sélectionnés pour ce numéro en misant sur trois catégories : les études au niveau macro, les études au niveau micro, et les approches innovatrices. On propose également des orientations futures en soulignant l'exploitation de l'évaluation d'apprentissage afin d'augmenter la réciprocité communitaire, la sensibilité culturelle, l'apprentissage différencié, et l'accès à l'éducation à l'étranger.

\section{Abstract in Mandarin}

本篇引言概述了一期以留学教育为背景的关于教育学评估的特刊。此特刊旨在回答 这一中心问题 : 如何引导教育者有意识并具体地将学习目标, 学习背景, 与学生的 能力和需要互相契合, 以便让学生获得预期的学习成果? 客座编辑简要描述了入选 在特刊的文章, 其中包括了宏观研究, 微观研究, 和创新方法三个类别。本文以借 助评估来增加留学教育中的群体互惠, 文化回应教学, 差异化学习和途径为中心, 对未来留学教育评估的发展方向提出了建议。

How can we guide educators toward specific and intentional alignment of learning objectives, the learning context, and learner capacities and needs so that students achieve the desired learning outcomes? This question emerges from our daily work with faculty and staff through Purdue University's Center for Intercultural Learning, Mentorship, Assessment and Research, whose mission is to promote and facilitate intercultural learning opportunities for the entire campus community. This question is particularly relevant to the field of education abroad in the current moment when the boundaries of that field are in question due to global suspensions of (physical) travel opportunities and renewed public scrutiny of systemized inequities. Assessment is indispensable as we seek to address these issues. We developed this special issue around the theme of Assessment as Pedagogy to highlight the importance of these topics in 
education abroad. We have assembled a collection of articles that address these and other important questions.

Traditionally, quality in mobility education has primarily been determined with reference to program characteristics such as length and depth of immersion and easily quantifiable outputs like retention. More recently, however, researchers in the field have begun to turn their attention to defining and measuring learning outcomes and using assessment data to evaluate program quality (Salisbury, 2015). Yet, in the education abroad literature, there is a paucity of work which discusses the alignment of learning goals, pedagogy, feedback, and outcomes. Few published articles in the education abroad literature talk about formative assessment (e.g., low stakes individualized goalsetting and feedback loops), or about alignment of the research method and instrument(s) with the learning objectives and the course assignments. Nor do they openly talk about improvements made after outcomes assessment was performed, a continuous improvement approach advocated in the Forum's Standards of Good Practice for Education Abroad. Having come so far in recognizing the importance of assessment in general, the field of education abroad now needs a clearly delineated set of evidence-based best practices specifically for using assessment pedagogically -- assessment recentered on the learners.

Also necessary are models that education abroad professionals can follow to put principles into practice at the program level, and, in addition, given the increased numbers of students studying abroad globally, models for scaling up learning and assessment to larger groups of students. When learners receive timely feedback on their progress and processes, they are better able to set learning goals, maintain motivation and engagement, and achieve intended learning outcomes. In this way, the purpose of assessment includes not only improving future iterations of the course or program but also boosting skill mastery for current learners.

In our February, 2020 virtual issue on Assessment as Pedagogy, which reviewed and summarized roughly 24 years of Frontiers articles (e.g. Vol.1 -Vol. 30), we found that the majority of articles that used an assessment instrument fell more within the program evaluation or research paradigms than within the definition of assessment as it is used by educational assessment professionals.

\begin{tabular}{ll} 
Category & Description \\
\hline Research & A truth-seeking activity which aims to uncover generalizable knowledge. \\
Program & Seeks to establish the worth or impact of an intervention or program, \\
Evaluation & $\begin{array}{l}\text { often in comparison to a standard. } \\
\text { Assessment }\end{array}$ \\
& $\begin{array}{l}\text { Seeks primarily to improve student learning. May also, at the institutional } \\
\text { or system level, wish to establish the effectiveness of efforts intended to } \\
\text { produce student learning. }\end{array}$
\end{tabular}


Because assessment should focus primarily on improving student learning, in that virtual issue we highlighted articles that focused on formative assessment, that looked at the degree to which education abroad can contribute to institutional learning goals, or that discussed the use of backwards design principles to align outcome goals and assessment measures with specific pedagogical choices. Done right, assessment provides an operational roadmap for inclusive excellence - meaning that it takes into account contextual factors such as learners' differing preparedness for learning, aptitudes, and motivations, as well as instructors' skill in implementing curriculum and a variety of other factors that impact which students achieve intended learning outcomes.

This special issue of Frontiers centers on this specific practice of assessment as pedagogy, also sometimes referred to by various terms such as formative assessment, baseline analysis, feedback to learners, in-process evaluation, and assessment as (rather than of or for) learning. We present recent cutting-edge empirical studies and theoretical reflections which uphold assessment as a learner-centered pedagogy and as an internally-motivated integral part of the learning-mentoring-teaching process, as well as a valued faculty and staff professional development tool.

\section{Thematic Summary of Contributions}

For this issue, our intent was to highlight articles that eloquently illustrate backwards design, formative assessment and/or investigation and improvement of learning at the institutional level. We were gratified to receive many high-quality submissions in answer to our call. All articles well aligned with the special issue theme of pedagogical uses of assessment went through a double-blind review process, as well as review by at least two members of the guest editorial team. The following themes bubbled up from accepted submissions and are by no means representative of the full range of possibilities for assessment as pedagogy: macro-level studies, micro-level studies, and innovative approaches to assessment in education abroad.

\section{Macro-Level Studies}

At the macro level, the purpose of assessment is to improve the learning outcomes of more than a single course. In its design and execution, macro-level assessment closely mirrors program evaluation: It seeks primarily to discover or prove the value-added effect of a certain pedagogical approach or large-scale educational intervention. Macro-level assessment often (although not always) relies upon quantitative methods in order to justify large-scale change, yet it differs from program evaluation in having been designed to intentionally and iteratively incorporate findings into improvements of the learning 
environment. Of the possible ways to embody assessment as pedagogy in an article or study, macro-level assessment has historically been underrepresented in the education abroad literature, quite possibly because it requires more significant investments of time, effort, and funds, often coordinated across multiple units or even institutions. (The research paradigms which have thus far driven assessment in education abroad have also often led to concerns about generalizability, when faced with a variety of education abroad program formats, lengths, destinations, etc. ${ }^{1}$ ) Our first three articles in this special issue are therefore distinctive additions to the literature due to the breadth of their scope.

We open the section with Baiutti's article, "Developing and Assessing Intercultural Competence during a Mobility Programme for Pupils in Upper Secondary School: The Intercultura Assessment Protocol," which describes the development and application of an assessment tool, the IAP framework, designed to help secondary school teachers in Italy define, document, and verify the learning that arises from widespread pupil mobility. This study offers a rich, rigorous, and nuanced example of how to build large-scale instructor consensus around assessment in support of comprehensive internationalization goals. The second article, "The Bentley Global Experience Initiative: An Application of Assessment Data towards Pedagogical Development," by Berdrow and colleagues, highlights an important emerging trend in the assessment and teaching of "global" competencies. Building on nine years' experience of assessing undergraduate general education outcomes with an intercultural competence tool (the Intercultural Effectiveness Scale), a private US university redesigns its general education curriculum to include a required global or domestic intercultural immersion component - and discusses the learning outcome findings. The third and last article in this group, "Assessment as Pedagogy in a Compressed-Format Summer Physics Abroad Program" by Ho and colleagues, qualifies as macro-analysis for its comparative analysis of a single summer intensive physics program offered for US undergraduates in collaboration with university partners in England, Scotland, and Ireland. Comparing case studies from each site, it examines how pedagogy has shifted and improved over time through the increased use of formative assessment techniques, including mobile application-based reflection and feedback.

\footnotetext{
${ }^{1}$ Editors' Note: It is our position that the existing research on education abroad outcomes strongly suggests that format, length, and destination of program matter very little as compared to cultural mentoring. For more on this, see, e.g., Vande Berg, Connor-Linton \& Page, 2009; Anderson, Lorenz \& White, 2016.
} 


\section{Micro-Level Studies}

At the micro-level, assessment looks at a particular program, learning intervention, or student experience, and often resembles either research (seeking generalizable findings) or program evaluation (benchmarking) but with a focus on improving student learning. Assessment as pedagogy is particularly interested in alignment between outcomes, assessment, and learning experiences. We offer three articles that fit within this paradigm, all depicting snapshots from multi-year efforts where the instructional team was intentional about alignment of a specific course and centered on student development from day one.

Our first offering in this section, "Constructing the Learning Outcomes with Intercultural Assessment: A 3-Year Study of a Graduate Study Abroad and Glocal Experience Programs," by Cartwright and colleagues, is unusual within the Frontiers canon for assessing the outcomes of MBA students. This summer intensive program offered the same curriculum in tandem with either an international or a US-based "glocal" immersion experience. They showcase the formative use of the AAC\&U intercultural competence rubric and paired peer feedback on personalized development plans based on individual results from the Intercultural Effectiveness Scale. Next, "Evaluating an Intensive Program to Increase Cultural Intelligence: A Quasi-Experimental Design,” by Chang Alexander and colleagues juxtaposes an embedded faculty-led study abroad health sciences program with an on-campus course. They gathered summative data with the Cultural Intelligence Scale (CQS) and provided formative assessment through guided reflection exercises, group debriefing and instructor feedback. The final micro-analysis article, "Using the BEVI to Assess Individual Experience to Enhance International Programming,” by Grant and colleagues, grew out of an MS thesis in Agriculture. The authors leveraged the Beliefs, Events and Values Inventory (BEVI) as both a summative and formative assessment to support intercultural learning of Animal Science undergraduates, who studied abroad in company with a group of community education professionals.

\section{Innovative Approaches}

Since Frontiers' inception, the dominant paradigm for excellence in articles has aligned strongly with Eurocentric norms for scholarly inquiry. The field of assessment, growing from similar institutional contexts, has often shared or even reified those norms. Today, particularly, beyond the education abroad professional enclave, assessment work is increasingly shaped by other paradigms: student-centered methodologies (Harper \& Kuh, 2007; Lapp, Fisher, \& Frey, 2013), critical theory and pedagogy (Heiser, Prince \& Levy, 2018), data feminism (D’Ignazio \& Klein, 2020) and assessment as and for social justice 
(Lundquist \& Henning, 2020; Symonette, Miller \& Barela, 2020). In this final section of the special issue, we therefore feature articles meant to encourage international educators to challenge possible institutional biases about data collection, instruments, or methodologies and data analysis for assessment (as well as for research and program evaluation) and to consider a broader range of methodologies.

To what extent does evaluation discourage learner authenticity, engagement, and transformation? Can we just eliminate grading for experiential learning? Our first article in this section is from Australian scholars Hardy and Totman. "Taking a Pass on Assessment Grades for a Career Focused Tour of the Middle East” discusses the pedagogical tensions between learners who feel competitive about grades, instructors who hope to eliminate grading to help learners refine and redefine career choices through study abroad, and a university system that requires that all courses be assessed. Next, in "Culturally Conscious Assessment as Pedagogy in Study Abroad: A Case Study of the Higher Education in the Ghanaian Context Program," Martin discusses the assessment ethos and structure of a study abroad program for student affairs and higher education professionals conducted in partnership with Ghanaian educators. The assessment approach draws upon culturally responsive pedagogy to decenter Whiteness and decolonize learning using action research, reflective sharing, and empowerment evaluation. Our third entry in this grouping, "Capturing Photo Narratives in Short-Term Study Abroad," by Nguyen, could easily have fit in the macro-level grouping since it assesses 80 visual artifacts of learning from eight different short-term study abroad programs. We place it in the innovation section, though, to highlight the way photo-narrative techniques and reflective learning activities elicit deeper learning among study abroad participants. The author integrates visual ethnography techniques and intercultural development theory, turning photos into data that helps us interpret and document student growth. The final jewel in our collection, "To Understand You, I Need to Know Me: Approximating the Study Abroad Experience Utilizing Assessment as Learning in a Glocal Classroom,” authored by Dunn-Jensen and colleagues, addresses an essential, structural inequity of most forms of education abroad: that the perceived need for physical relocation of the learner often restricts participation to those with privilege. The study describes the application of cognitive-based therapy (behavior-changing) methods and formative assessment using the Intercultural Effectiveness Scale to create a 15-week on-campus learning experience that attempts to replicate the job demands, cognitive dissonance and work contexts of an international internship placement. 


\section{Future Directions}

It has been a pleasure for our guest editorial team to work with the Frontiers staff, the authors, and the many reviewers who made this project possible. In reflecting back on the process and the finished project, we have thoughts about the strengths of this special issue and directions for future research that the included manuscripts suggest.

Being serious about assessment-as-pedagogy demands that we pay attention to who is made welcome and who is marginalized within the learning context. Recently, Frontiers published a special issue on Diversity, Equity and Inclusion in Education Abroad (Contreras, López-McGee, Wick, \& Willis, 2020) that sought "to push beyond discussions of access and representation in the field to critically examine inclusion throughout the education abroad process, and to consider equity in outcomes” (p. 1). In early 2021, members of NAFSA's Education Abroad knowledge community, articulated an “...anti-racist framework for study abroad” (Contreras, Montgomery, and Sevilla-Garcia). In a similar vein, assessment in education abroad needs to systematically decenter Whiteness. Doing so requires going beyond the production of scholarly literature to forming new habits in practice, for example:

- assessing community impacts and not just sojourner learning

- gathering assessment data from all (not just "our") students participating in exchanges or other intercultural learning interventions,

- mindfully practicing more culturally responsive assessment appropriate for different learner needs, and

- intentionally leveraging assessment to open access to education abroad.

This issue offers a point of departure for these and other inclusivity efforts. Although our collection of articles showcases a range of instruments and methods, many more innovative models and measures deserve to be explained and exemplified for practitioners. Likewise, the articles include discussion of assessment as pedagogy in three STEM disciplines: physics, health sciences, and animal science. STEM education abroad programs and the corresponding assessment are growing, but the pedagogy and assessment literature does not represent this well outside of the proceedings of annual conferences on Engineering Education.

Finally, this project began before the novel coronavirus upended the field of education abroad and protests in response to the killing of Black people by US police amplified the call for racial justice around the world. In alignment 
with calls to understand global education as a continuum with mobility programs at one end and intercultural learning for all students on campus at the other (Leask \& Green, 2020; Ogden, 2021), we would like to see our discipline and Frontiers continue to adapt and to address more resolutely matters of equity and belongingness. For example, Virtual Exchange (VE) can afford more than an emergency short-term stopgap. VE deserves the serious assessment of learning outcomes that can help grant it legitimacy and ensure that technology supports accessibility rather than becoming yet another tool of exclusion. Similarly, assessment can demonstrate that in-country or domestic study away programs may offer equally powerful and effective opportunities for cultural learning. Assessment, applied pedagogically, can help us push the boundaries of education abroad while continually improving what our field offers all life-long learners - participants, leaders, and community members alike.

Our aim in editing this special issue was to provide models of research and practices in assessment as pedagogy and to contribute to our own unit's mission of facilitating intercultural learning opportunities and fostering inclusion, belongingness, and community. In this special issue we hope the education abroad community will find both grounding information and ongoing inspiration for institutions and instructors to employ more researchbased and innovative practices of assessment as pedagogy. The future can be daunting, but we believe the curious and courageous soul of education abroad is up to the journey.

\section{References}

Acheson, K., Yngve, K., Stahl, A., \& Jin, L. (Eds.). (2020). Virtual issue on recent research in assessment in education abroad. Frontiers: Interdisciplinary Journal of Study Abroad, 32. https://doi.org/10.36366/frontiers.v32iVirtual

Anderson, C. L., Lorenz, K., \& White, M. (2016). Instructor Influence on Student Intercultural Gains and Learning during Instructor-Led, Short-Term Study Abroad. Frontiers: The Interdisciplinary Journal of Study Abroad, 28(1), 1-23. https://doi.org/10.36366/frontiers.v28i1.377

Contreras, E., Montgomery, M., \& Sevilla-Garcia, H. (January 5th, 2021). An anti-racist framework for Education Abroad, NAFSA Education Abroad Practice Area Column [blog]. https://www.nafsa.org/ie-magazine/2021/1/5/antiracist-framework-education-abroad

Contreras, Jr. , E., López-McGee, L., Wick, D., \& Willis, T. Y. (Eds.). (2020). Special issue on diversity, equity, and inclusion in education abroad. Frontiers: Interdisciplinary Journal of Study Abroad, 32(1). https://doi.org/10.36366/frontiers.v32i1

D'Ignazio, C., \& Klein, L. F. (2020). Data feminism. Mit Press.

Harper, S. R., \& Kuh, G. D. (2007). Myths and misconceptions about using qualitative methods in assessment. New Directions for Institutional Research, 2007(136), 5-14.

Heiser, C. A., Prince, K., \& Levy, J. D. (2017). Examining critical theory as a framework to advance equity through student affairs assessment. Journal of Student Affairs Inquiry, 3(1), 1621.

Lapp, D., Fisher, D., \& Frey, N. (2013). Feed-forward: Linking instruction with assessment. Voices from the Middle, 21(2), 7.

Leask, B. \& Green, W. (2020, May 2). Is the pandemic a watershed for internationalisation? University World News. https://www.universityworldnews.com/post.php?story=20200501141641136

Lundquist, A. E., \& Henning, G. (2020). From Avoiding Bias to Social Justice: A Continuum of Assessment Practices to Advance Diversity, Equity, and Inclusion. In Developing an Intercultural Responsive Leadership Style for Faculty and Administrators (pp. 47-61). IGI Global. 
Ogden, A.C. (2021, January 23). Do we need a new definition of education abroad post-COVID? University World News. https://www.universityworldnews.com/post.php?story=20210119095105638

Salisbury, M. (2015). How we got to where we are (and aren't) in assessing study abroad learning. In V. Savicki \& E. Brewer (Eds.), Assessing study abroad: Theory, tools, and practice, (pp.15-32). Sterling, VA: Stylus.

Symonette, H., Miller, R. L., \& Barela, E. (2020). Power, privilege, and competence: using the 2018 Evaluator Competencies to shape socially just evaluation practice. In J.A. King (Ed.), The American Evaluation Association's Program Evaluator Competencies. New Directions for Evaluation, 2020, 117-132.

Vande Berg, M., Connor-Linton, J., \& Paige, R. M. (2009). The Georgetown Consortium Project: Interventions for Student Learning Abroad. Frontiers: The Interdisciplinary Journal of Study Abroad, 18(1), 1-75. https://doi.org/10.36366/frontiers.v18i1.251

\section{Guest Editor Biographies}

Kris Acheson earned a $\mathrm{PhD}$ in Intercultural Communication in 2008 from Arizona State University. She served as faculty in Applied Linguistics at Georgia State for 6 years and as a Fulbright Scholar to Honduras in 2015. At Purdue University, Dr. Acheson-Clair directs the Center for Intercultural Learning, Mentorship, Assessment and Research (CILMAR). She is a well-published scholar in the area of intercultural competence development and assessment.

Lan Jin earned a PhD in Consumer Behavior in 2017 from Purdue University. She is currently an Intercultural Research Specialist in the Center for Intercultural Learning, Mentorship, Assessment and Research (CILMAR) at Purdue University. Her major research interests lie in the area of intercultural competence development and diversity, equity, and inclusion in higher education. She is particularly interested in developing intercultural interventions using innovative approaches to improve intercultural competence and other student learning outcomes.

Aletha Stahl earned a PhD in Comparative Literature from the University of Iowa and was formerly Professor of French and Francophone Studies at Earlham College where she developed and led programs in Martinique, Haiti, and Benin among others. At Purdue University, she serves as a Senior Intercultural Learning Specialist in the Center for Intercultural Learning, Mentorship, Assessment and Research (CILMAR), focusing on curricular needs assessments and intervention design related to intercultural learning.

Katherine Yngve, a "recovering” Senior International Officer (American University of Beirut), now works for Purdue's Institutional Data Analysis + Assessment ("IDATA") team. She specializes in scaling up of evidence-based intercultural and diversity learning in on-campus, virtual and overseas learning contexts. A founding content-creator for NAFSA's Teaching, Learning \& Scholarship community, she is now the "assessment sage" for the Intercultural Learning Hub (www.hubicl.org), and co-founder of Purdue’s new Community of Practice on Socially Just Assessment. 